Original paper

DOI: 10.2478/agri-2021-0010

\title{
MINERAL COMPOSITION OF POTTED CABBAGE (BRASSICA OLERACEA VAR. CAPITATA L.) GROWN IN ZEOLITE AMENDED SANDY SOIL
}

\author{
OLWETU A. SINDESI ${ }^{1}$, MUINAT N. LEWU², BONGANI NCUBE ${ }^{3 *}$, RECKSON MULIDZI $^{2}$, \\ AND FRANCIS B. LEWU ${ }^{1}$
}

${ }^{1}$ Cape Peninsula University of Technology, Wellington, South Africa

${ }^{2}$ Soil and Water Science Programme, Stellenbosch, South Africa

${ }^{3}$ Cape Peninsula University of Technology, Cape Town, South Africa

Sindesi, O.A, Lewu, M.N., Ncube, B., Mulidzi, R. and Lewu, F. (2021). Mineral composition of potted cabbage (Brassica oleracea var. capitata L.) grown in zeolite amended sandy soil. Agriculture (Polnohospodárstvo), 67(3), $103-112$.

\begin{abstract}
Vegetables are essential components in human diets because they are rich in vitamins, minerals, and dietary fibre. There is a growing interest in human nutrition enhancement through vegetable consumption to reduce micro mineral deficiencies, especially in households with low buying power. A greenhouse pot experiment was conducted to evaluate the effect of zeolite amendment on the mineral composition of cabbage (Brassica oleracea var. capitata L.), in relation to the soil chemical status. The experiment was carried out over two growing seasons (winter/spring) of 2018 and 2019. The treatments were in the ratios of $0: 10,1: 9,2: 8,3: 7$ zeolite to sandy soil, on a weight-to-weight basis. Zeolite improved soil chemical status $(p<0.05)$, except for soil iron $(\mathrm{Fe})$ and phosphorus $(\mathrm{P})$ contents. There was also a general improvement of macro minerals in cabbage with increased zeolite application, especially in the second season. Zeolite did not improve the micronutrients of the vegetable. This indicates that cabbage planted under zeolite amended soils provides no additional contribution to the fight against micronutrient deficiencies. However, zeolite showed potential for soil conditioning in soil macronutrients and soil $\mathrm{pH}$.
\end{abstract}

Key words: cabbage, zeolite, soil conditioner, soil amendment, soil fertility

Fruits and vegetables are essential in human diets due to their nutritional value arising from high mineral, vitamin, and dietary fibre content (Cvetković et al. 2019). Diets high in fruits and vegetables have been associated with reduced risks of numerous chronic diseases, including cancer and cardiovascular diseases, and maintaining healthy body weight. Nutrient content and total nutritional benefits of fruits and vegetables depend on the crop cultivar, agricultural production practices, and ripening stage
(Cvetković et al. 2019). There is an interest in the nutritional enhancement of highly utilised vegetables, especially, using them to reduce micro mineral deficiencies in humans (Mzoughi et al. 2019).

Micro mineral deficiency is a widespread public health problem. It is the result of the low bioactivity of trace minerals, particularly iron $(\mathrm{Fe})$ in the daily diet (Tulchinsky 2010). Micro mineral deficiencies have been combated by increasing dietary plant varieties in diets (Mzoughi et al. 2019). However, in

Olwetu A. Sindesi, Francis B. Lewu, Department of Agriculture, Faculty of Applied Sciences, Cape Peninsula University of Technology, Private Bag X8, Wellington 7654, South Africa

Muinat N. Lewu, Reckson Mulidzi, Soil and Water Science Programme, ARC Infruitec-Nietvoorbij, Private Bag X5026, Stellenbosch 7599, South Africa

Bongani Ncube (*Corresponding author), Centre for Water and Sanitation Research, Department of Civil Engineering and Surveying, Faculty of Engineering \& the Built Environment, Cape Peninsula University of Technology, Bellville 7535, Cape Town, South Africa. E-mail: ncubeb@cput.ac.za 
poor households, buying power is limited to a few products at a time (Headey \& Martin 2016).

Increasing the nutritional contents of vegetables with agricultural practices is one of the ways of improving the micronutrient contents in food crops (Bernacchia et al. 2016). This can be through the manipulation of factors governing soil nutrient availability. Soil $\mathrm{pH}$ is part of the main factors that govern the solubility and bioavailability of soil elements leading to the accumulation of nutrients in plants (Clemente et al. 2005). Other factors include soil physical, chemical, and biological properties, as they condition plant growth and survival in soil (Bernacchia et al. 2016).

Amendments such as zeolite have shown the potential to mitigate soil acidity and improve soil physiological and chemical properties (de Campos Bernardi et al. 2013; Ramesh et al. 2015). Zeolites are aluminosilicate minerals (Gül et al. 2005), that are alkaline, porous structured, with a high cation exchange capacity (CEC), and great affinity for ammonium $\left(\mathrm{NH}_{4}^{+}\right)$cations (He et al. 2002; Ahmed et al. 2008). Zeolite applicability to agriculture has been linked to its (i) high cation exchange; (ii) high water-holding capacity and (iii) high absorption capacity (de Campos Bernardi et al. 2013). In heavy metal contaminated soils, zeolite has been shown to reduce their bioavailability due to their negative charge (Garau et al. 2007). Heavy metals are not easily biodegradable and persist in soils for long periods (Garau et al. 2007; Ramesh \& Reddy 2011) and their competitiveness in soils may account for the unavailability of some of the essential plant micronutrients. Zeolite accelerates the soil natural reactions which reduce mobility and bioavailability of heavy metals to plants (Madejón et al. 2006).

The impact of zeolite on plant growth, yield, and crop mineral composition has been investigated in other studies (Gül et al. 2005; Ahmed et al. 2008; Eshghi et al. 2010; Ramesh \& Reddy 2011; Zbahce et al. 2015; Ramesh et al. 2015; Hazrati et al. 2017). However, zeolite use for crop production has not received much interest, especially in South Africa. There is limited information on the impact of zeolite on the mineral composition of vegetables such as cabbage (Brassica oleracea var. capitata L.), which is a major part of the South African diet (Afolayan \& Jimoh 2009; Bvenura \& Afolayan 2015). This study aimed to evaluate the effect of zeolite on the mineral composition of cabbage, in relation to soil chemical status.

\section{MATERIAL AND METHODS}

\section{Experimental site and treatment details}

A greenhouse pot experiment was conducted at the Agricultural Research Council (ARC) Infruitec-Nietvoorbij, Stellenbosch, South Africa $\left(33.914476^{\circ} \mathrm{S}\right.$ and $\left.18.861322^{\circ} \mathrm{E}\right)$. Six-week-old cabbage (cv. Copenhagen) seedlings were transplanted into potted zeolite amended sandy soil and studied over two growing seasons (winter/spring, 2018 and 2019). The treatments were: $0 \%$ zeolite $+100 \%$ sandy soil, $10 \%$ zeolite $+90 \%$ sandy soil, $20 \%$ zeolite $+80 \%$ sandy soil and $30 \%$ zeolite + $70 \%$ sandy soil (i.e. ratios of $0: 10,1: 9,2: 8,3: 7$ zeolite to sandy soil) on a weight by weight basis. Treatments were replicated 6 times and arranged in a randomized complete block design. The total weight of soil or soil and zeolite per pot was $12 \mathrm{~kg}$. Urea $(46 \% \mathrm{~N})$ and single-super phosphate $(20 \% \mathrm{P})$ was applied to all pots at a rate of 1.17 and $3 \mathrm{~g} / \mathrm{pot}$ respectively, while potassium chloride $(50 \% \mathrm{~K})$ was applied at $1.92 \mathrm{~g} /$ pot before transplanting. Additionally, a urea side-dress of $1.11 \mathrm{~g} /$ pot was applied in split applications at 3 and 6 weeks after transplanting (WAT). Seedlings were planted at one seedling per pot into $30 \mathrm{~cm}$ diameter and depth plastic pots. Soil water content was regularly monitored gravimetrically and through the weighing of pots. Irrigation water was maintained above $50 \%$ field capacity (FC) throughout the study.

Weeds were manually removed while insect pests were controlled with Makhro Cyper ${ }^{\circledR}$ (active ingredient: cypermethrin, $200 \mathrm{~g} / \mathrm{L}$ ), using $1 \mathrm{~mL}$ in $10 \mathrm{~L}$ of water in the first growing season. In the second growing season, Avi Gard Mercaptothion ${ }^{\circledR}$ (active ingredient Organophosphate $500 \mathrm{~g} / \mathrm{L}$ ) was used to control pests at a rate of $15 \mathrm{~mL}$ of chemical to $10 \mathrm{~L}$ of water. The pesticide had to be changed because the pests appeared to develop immunity against the first pesticide.

\section{Harvesting and sample processing}

Harvesting was done 126 days after transplant- 
ing (DAT), by cutting the stem close to the head. The head was then chopped into small pieces and oven-dried at $70^{\circ} \mathrm{C}$ in a forced-air oven till constant weight. Dry samples were separately milled using the Polymix PX-MFC, 90D miller manufactured by Kinemanetica AG, Switzerland. The milled samples were placed in well labelled airtight containers and later stored in the refrigerator before mineral analysis.

\section{Plant tissue analysis}

To determine the mineral element composition, the plant samples were dry-ashed in a muffle furnace at $500^{\circ} \mathrm{C}$ for $6 \mathrm{hr}$ and extracted using hydrochloric acid for total acid digestion in the determination of phosphorus $(\mathrm{P})$, potassium $(\mathrm{K})$, calcium $(\mathrm{Ca})$, magnesium $(\mathrm{Mg})$, sodium $(\mathrm{Na})$, manganese $(\mathrm{Mn})$, iron $(\mathrm{Fe})$, copper $(\mathrm{Cu})$ and zinc $(\mathrm{Zn})$.

\section{Soil chemical analysis}

Standard baseline soil chemical analysis was carried out before the application of treatments and again at harvest (for both seasons) using the standard procedures of the Non-affiliated Soil Analysis Work Committee (1990). Total available P, K, and soil $\mathrm{pH}$ were determined using ICP-OES Bray II, Tetraphenylboron, and Potassium Chloride $(\mathrm{KCl})$ methods respectively. Soil exchangeable $\mathrm{Ca}, \mathrm{Mg}$, and $\mathrm{Na}$ were extracted using $1.0 \mathrm{~N}$ ammonium acetate while $\mathrm{Fe}, \mathrm{Cu}, \mathrm{Mn}$, and $\mathrm{Zn}$ were determined by the EDTA (ethylene diamine tetraacetic acid) titration method. All reagents used for chemical analysis were of analytical grade.

\section{Statistical analysis}

Data were subjected to analysis of variance (ANOVA) using SAS (version 9.4, SAS Institute Inc., Cary, NC, USA, 2000). ANOVA was done per season, using SAS statistical software. Results of both seasons were also combined and investigated in one overall ANOVA after testing for season homogeneity of variance using Levene's test. The Shapiro-Wilk test was performed to test for deviation from normality. Fisher's least significant difference was calculated at the $5 \%$ level to compare treatment means. A probability level of $5 \%$ was considered significant for all tests.

\section{RESULTS AND DISCUSSION}

Table 1 presents the soil baseline chemical properties at the commencement of the study while the composition and characteristics of zeolite used as a soil amendment in this study are presented in Table 2.

Cabbage macro mineral contents in relation to soil
nutrient availability and zeolite application

The macronutrient contents of the cabbage head evaluated in this study are presented in Figure 1. In the second season of the study, the level of $\mathrm{P}$ in cabbage heads generally increased $(p<0.05)$ with the increase in soil zeolite application, unlike in the first growing season where there was no significant difference. Cabbage P contents in the first season were consistent with the findings of (Pasković et al. 2013) where there was no significant difference in $\mathrm{P}$ with zeolite application. However, the second season's results followed the trend also observed by (Zheng et al. 2019) on rice grown under zeolite application.

In relation to soil $\mathrm{P}$ (Figure 2), $\mathrm{P}$ contents in the soil did not follow the trend observed in cabbage P. In both seasons, soil P significantly decreased $(p<0.05)$ with the increase in zeolite application (Figure 2). Soil P in this study was in contrast with

T a b 1 e 1

Soil baseline chemical properties

\begin{tabular}{|l|c|}
\hline Soil parameter & Value \\
\hline $\mathrm{pH}_{(\mathrm{KCl})}$ & 5.4 \\
\hline \multicolumn{2}{|c|}{$[\mathrm{mg} / \mathrm{kg}]$} \\
\hline Phosphorus (P) & 47.0 \\
Potassium (K) & 47.0 \\
Iron (Fe) & 362.0 \\
Zinc (Zn) & 6.2 \\
Manganese (Mn) & 24.2 \\
Copper (Cu) & 0.4 \\
\hline \multicolumn{2}{|c|}{ Exchangeable cations [cmol/kg] } \\
\hline Calcium (Ca) & 5.83 \\
Magnesium (Mg) & 0.39 \\
Sodium (Na) & 0.11 \\
\hline
\end{tabular}

$\mathrm{KCl}-\mathrm{pH}$ measured in potassium chloride solution. 
the findings of previous studies (Ozbahce et al. 2015, 2018; Zheng et al. 2019) who all found soil $\mathrm{P}$ to increase with increased zeolite application. Soil $\mathrm{P}$ is hypothetically made available by the application of zeolite, as reactive products such as $\mathrm{Ca}^{2+}$ and $\mathrm{H}_{2} \mathrm{PO}^{4-}$ move into zeolites exchangeable sites thereby allowing for more $\mathrm{P}$ rock dissolution, making $\mathrm{P}$ to be readily available for plant assimilation (Nur Aainaa et al. 2018; Zheng et al. 2019). Soil $\mathrm{P}$ can be stored in the soil by adsorption, organic matter, soil solution, microbial biomass, etc. Soil P in the first season decreased even while there was no increase in cabbage $\mathrm{P}$ uptake, unlike in the second season where cabbage $\mathrm{P}$ increased thereby decreasing soil $P$ content after plant uptake.

In both growing seasons, cabbage grown on zeolite amended soil had higher levels of $\mathrm{K}$ and $\mathrm{Na}$ $(p<0.05)$ (Figure 1). The observed increase in $\mathrm{K}$ content in the cabbage head was in line with previous research findings (Gül et al. 2005), which found that zeolite as a soil conditioner was able to increase the content of both $\mathrm{N}$ and $\mathrm{K}$ in the plant tissue of crisp-head lettuce. The effect of zeolite on cabbage $\mathrm{K}$ content was however contradictory to other findings (Pasković et al. 2013) that found no significant difference in $\mathrm{K}$ of chicory cultivated under different
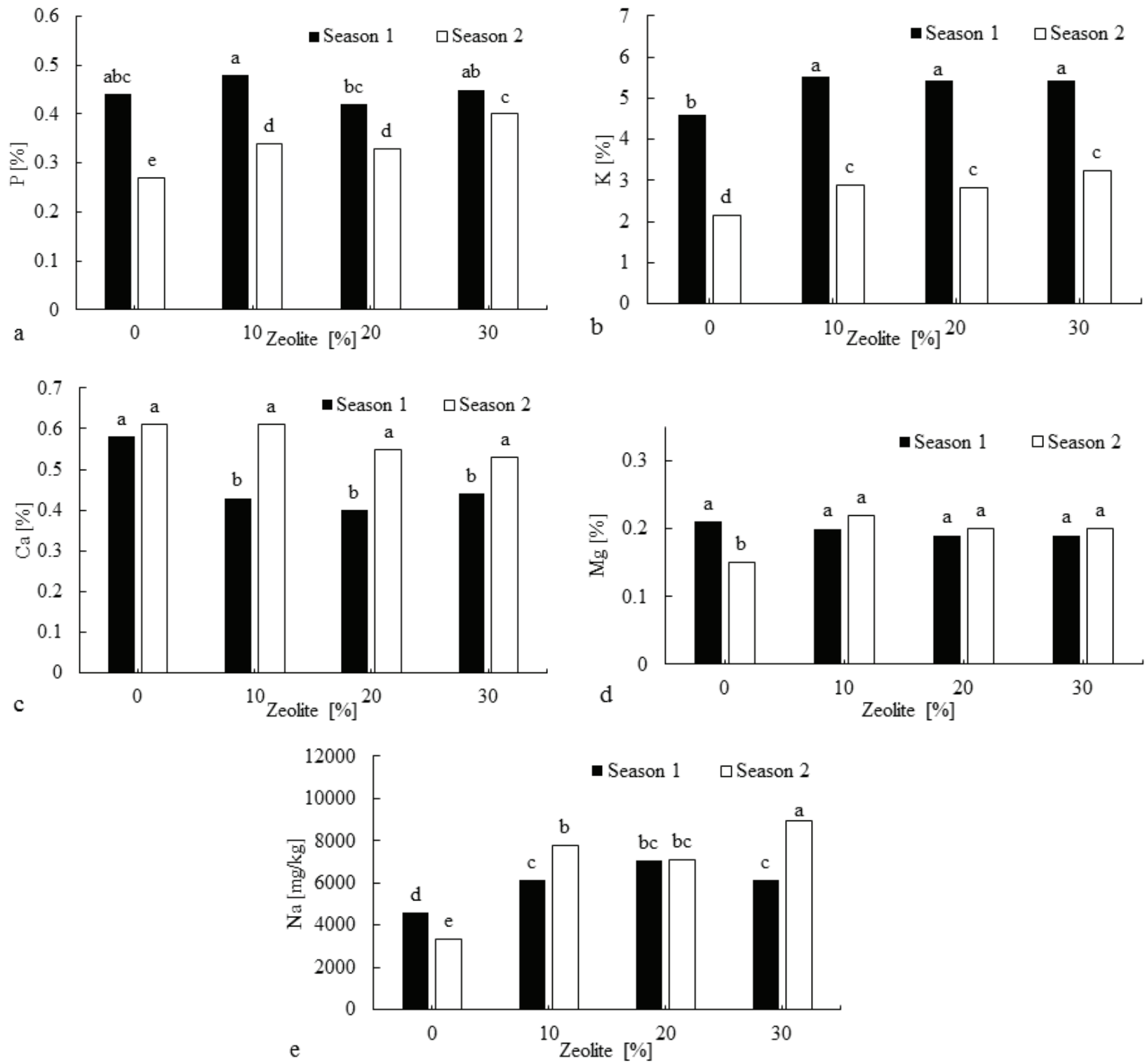

Figure 1. Cabbage macro mineral response to zeolite application $(\mathrm{a}-\mathrm{e})$. Bars with the same letters show no significance at $p<0.05$. Note: $\mathrm{P}$ - phosphorus; $\mathrm{K}$ - potassium; $\mathrm{Ca}$ - calcium; $\mathrm{Mg}$ - magnesium; $\mathrm{Na}$ - sodium. 
levels of zeolite. However, soil $\mathrm{K}$ and $\mathrm{Na}$ increased with an increase in zeolite application in both seasons (Figure 2). The increase may be attributed to the $2.3 \% \mathrm{Na}_{2} \mathrm{O}$ and $1.7 \% \mathrm{~K}_{2} \mathrm{O}$ in the zeolite composition (Table 2). Additionally, the soil $\mathrm{K}$ increase can also be associated with zeolites affinity towards $\mathrm{K}^{+}$cations (de Campos Bernardi et al. 2013; Ozbahce et al. 2018).

On the other hand, cabbage $\mathrm{Ca}$ and $\mathrm{Mg}$ content showed interchanging trends within the two seasons (Figure 1). In the first growing season, the amount of mineral Ca in the cabbage head reduced $(p<0.05)$ with the application of zeolite. However, in the second season, there was no significant difference in $\mathrm{Ca}$ levels on both zeolite amended sandy soils and the control ( $p>0.05)$, which is probably due to the residual effect of zeolite. Cabbage $\mathrm{Mg}$ content was also not affected $(p>0.05)$ in both growing seasons except for the observed drop that was recorded in

$\mathrm{T}$ a b 1 e 2

Zeolite characteristics

\begin{tabular}{|l|c|}
\hline Physical properties & Description \\
\hline Colour & White to grey \\
Appearance & Granules \\
$\mathrm{pH}(30 \mathrm{~g}$ in $60 \mathrm{~mL}$ water $)$ & 8 \\
Cation exchange capacity $[\mathrm{mg} / \mathrm{kg}]$ & 16 \\
Water adsorption $($ on sinter plate) & $400 \%$ \\
\hline Chemical property & Typical [\%] \\
\hline Silicon dioxide $\left(\mathrm{SiO}_{2}\right)$ & 64.3 \\
Aluminium oxide $\left(\mathrm{Al}_{2} \mathrm{O}_{3}\right)$ & 12.7 \\
Titanium dioxide $\left(\mathrm{TiO}_{2}\right)$ & 0.1 \\
Magnesium ooxide $(\mathrm{MgO})$ & 1.3 \\
Sodium oxide $\left(\mathrm{Na}_{2} \mathrm{O}\right)$ & 2.3 \\
Iron (III) oxide $\left(\mathrm{Fe}_{2} \mathrm{O}_{3}\right)$ & 1.3 \\
Calcium oxide $(\mathrm{CaO})$ & 1.2 \\
Potassium oxide $\left(\mathrm{K}_{2} \mathrm{O}\right)$ & 1.7 \\
Loss on ignition & 8.4 \\
\hline Mineralogy & Approximate \\
\hline Clinoptilolite $[\%]$ & $>90$ \\
Quartz [\%] & $<5$ \\
\hline
\end{tabular}

the non-amended sandy soil in the second season $(p<0.05)$. Soil exchangeable $\mathrm{Ca}$ and $\mathrm{Mg}$ generally increased $(p<0.05)$ with zeolite application (Figure 2). Nevertheless, there was less $\mathrm{Mg}$ in the soil in all treatments at the end of the second season compared to the $\mathrm{Mg}$ levels at the end of the first season. The increase in the exchangeable $\mathrm{Ca}$ and $\mathrm{Mg}$ (Figure 3) with the increase in zeolite application may be due to zeolite cation exchange capacity (CEC) and improved soil pH (Ramesh \& Reddy 2011).

The cabbage $\mathrm{Ca}, \mathrm{Mg}$, and $\mathrm{K}$ contents in this study were similar to previous findings (Pasković et al. 2013), although their results showed a non-significant increase ( $\mathrm{Mg}$ and $\mathrm{K}$ ) in chicory leaves with a decrease in $\mathrm{Ca}$ as a result of zeolite application. In another study (Gül et al. 2005) the contents of $\mathrm{Ca}$ and $\mathrm{Mg}$ were relatively low in crisp-head lettuce that was cultivated under zeolite than those cultivated under perlite. The results of this study were also similar to others where there were no significant differences in $\mathrm{Ca}$ and $\mathrm{Mg}$ contents in beans grown using different zeolite levels (Ozbahce et al. 2018). This was attributed to high soil $\mathrm{pH}$ and excessive soil $\mathrm{P}$. The $\mathrm{Ca}^{2+}$ cations moved to zeolite exchangeable sites which allowed more $\mathrm{P}$ availability while Ca became limited to plants (Nur Aainaa et al. 2018; Ozbahce et al. 2015; Zheng et al. 2019) and low solubility and mobility in soils, especially under water stress. Available soil P and plant P uptake could be improved through the application of zeolite. However, little is known about the impact of zeolite on $P$ uptake in rice under water stress. A two-year lysimetric experiment using a split-split plot design investigated the effects of zeolite ( 0 or $15 \mathrm{t} / \mathrm{ha})$. Cabbage $\mathrm{Ca}$ contents generally decreased in the first season while soil exchangeable $\mathrm{Ca}$ increased. High levels of $\mathrm{Ca}$ in soils have been proven to reduce the absorption of $\mathrm{Mg}$ and $\mathrm{K}$ in soils (Pasković et al. 2013), which was observed for $\mathrm{K}$ in this study. The increasing availability of these nutrients $(\mathrm{Ca}$, $\mathrm{Mg}$ and $\mathrm{K}$ ) in soil aligns with the increase in zeolite application in this study. These findings are in line with those obtained by other studies (Ozbahce et al. 2015; Ramesh \& Reddy 2011) who established that the application of zeolite to soil increased the availability of $\mathrm{Ca}, \mathrm{Mg}$, and $\mathrm{K}$. 
The response of soil trace elements and $\mathrm{pH}$ to zeolite application

Zeolite has been reported to have the ability to increase soil pH, similar to agricultural lime (Ramesh et al. 2015; Tsadilas et al. 1997). The baseline soil $\mathrm{pH}$ of 5.4 (Table 1) was near vegetable critical acidic values. However, the soil $\mathrm{pH}$ increased significantly $(p<0.05)$ with the application of zeolite (Figure 3$)$. This $\mathrm{pH}$ increase could be attributed to the alkaline nature, high CEC, and the negative charges of zeolite, which permit cation sorption (Nur Aainaa et al. 2018). This demonstrated the liming effect of zeolite in soils (Polat et al. 2004; Ramesh \& Reddy 2011). Zeolite has also been shown to adsorb heavy metals into its cavities and channels and further block their reception to plants by making the metal ions insoluble (de Campos Bernardi et al. 2013; Omar et al. 2011; Ramesh \& Reddy 2011; Reháková et al. 2004). Much of this has been attributed to the CEC of zeolite which exchanges plant nutrients and sorb soil heavy metals while slowly releasing the nutrient (Ramesh \& Reddy 2011), in addition to the alkalinity of zeolite which increases soil $\mathrm{pH}$. The adsorption of metals in soil is generally directly proportional to soil $\mathrm{pH}$, which also governs metal uptake by plants (Rieuwerts et al. 1998; Kukier et al. 2004; Fornes et al. 2009).

The soil micro minerals in this study responded differently to zeolite application between treatments and seasons (Figure 4). Soil $\mathrm{Zn}$ and $\mathrm{Cu}$ of the second
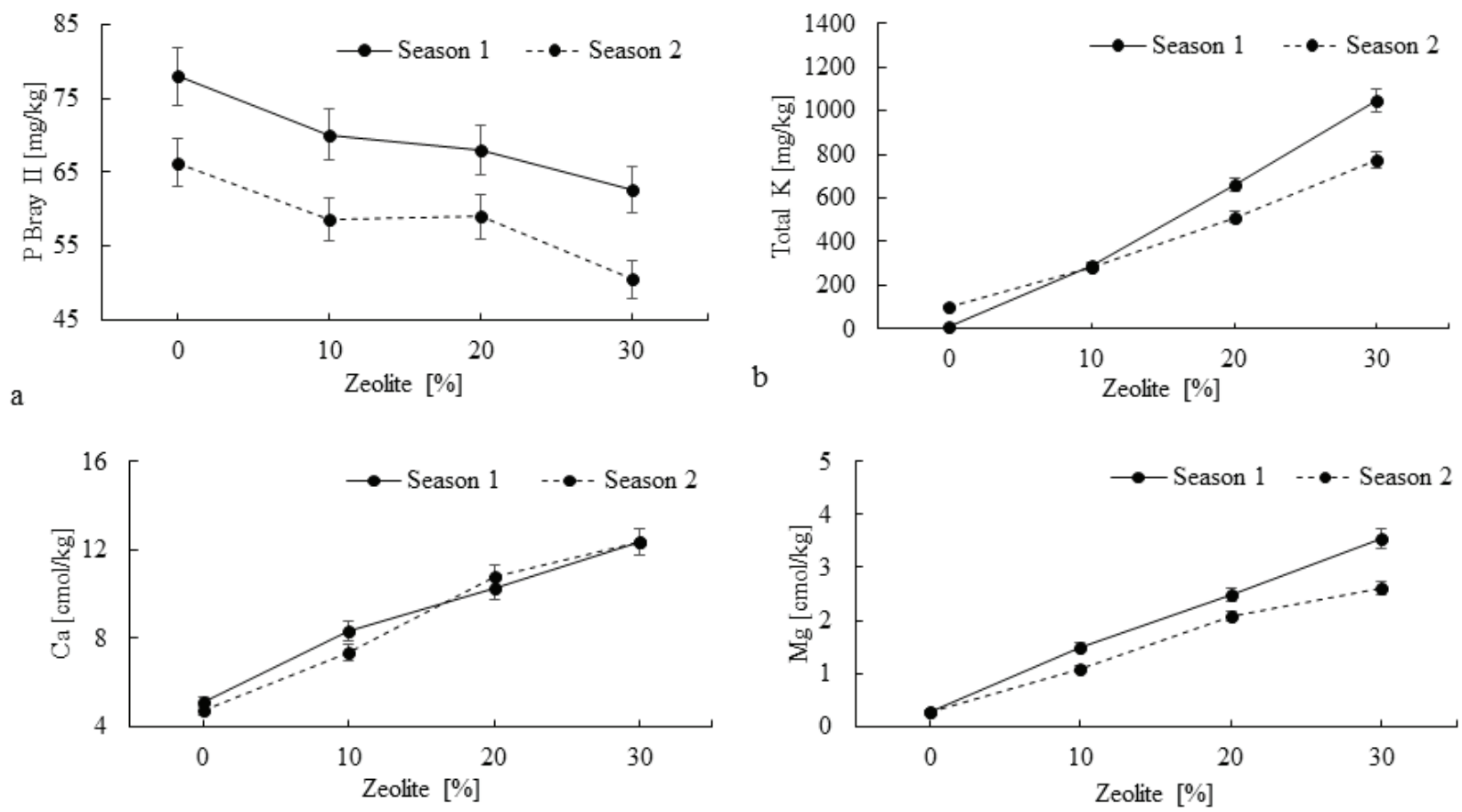

d

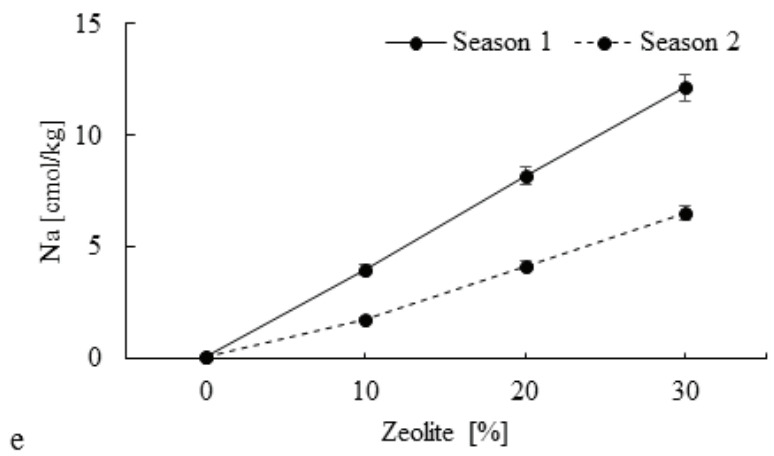

Figure 2. Effect of zeolite on soil macronutrients $(a-e)$. Overlapping error bars show no significance at $p<0.05$. Note: see Figure 1. 


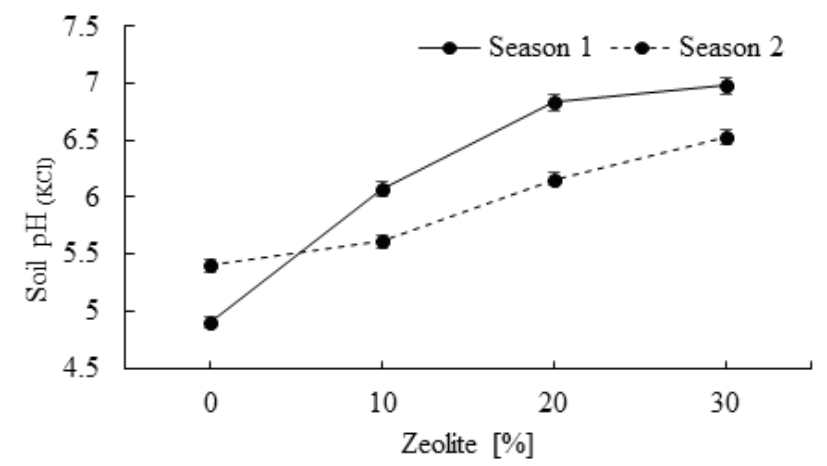

Figure 3. Effect of zeolite on soil $\mathrm{pH}$. Overlapping error bars show no significance at $p<0.05$. Note: $\mathrm{KCl}-$ see Table 1 .

season, and $\mathrm{Fe}$ in both seasons generally decreased with zeolite application, whereas soil $\mathrm{Zn}$ and $\mathrm{Cu}$ (first season) and Mn (both seasons) increased even though the soil $\mathrm{pH}$ increased with zeolite. This was similar to findings of an earlier study (Tsadilas et al. 1997) which found that zeolite increased the sorption of the heavy metal $\mathrm{Cd}$ on soils and as a result, it became insoluble and unavailable for plant assimilation. However, the increase in soil $\mathrm{Mn}$ in both seasons and $\mathrm{Zn}$ (second season) was similar to previous findings (Ozbahce et al. 2018), where soil $\mathrm{Zn}$ and $\mathrm{Mn}$ increases were linked to the presence in the zeolite used as a soil amendment. However, this was not the case for Fe. The applied zeolite contained Fe, but soil Fe was lower at the end of both growing seasons.

Micro mineral contents in cabbage head in response to zeolite application

All the micro minerals content of cabbage heads evaluated in this study were found to be at higher levels in the non-amended treatments, especially in the second season (Figure 5). $\mathrm{Fe}$ and $\mathrm{Cu}$ showed no significant difference $(p>0.05)$ in the first season among treatments while micro mineral $\mathrm{Zn}$ tended to decrease with increased zeolite application for both seasons. Similar to some previous studies (Reháková et al. 2004), zeolite resulted in a significant decrease in microelements in the cabbage plant tissues, except for $\mathrm{Mn}$ in the first growing season which had the highest content $(30.83 \mathrm{mg} / \mathrm{kg})$ in the $30 \%$ zeolite treatment.

$\mathrm{Fe}$ and $\mathrm{Zn}$ are essential micronutrients required for human growth and health. There is a widespread problem of these nutrient deficiencies among populations (Tulchinsky 2010; Kondaiah et al. 2019) but can be alleviated by supplementation and food fortification. Cross-sectional studies in humans showed positive association of serum zinc levels with hemoglobin and markers of iron status. Dietary restriction
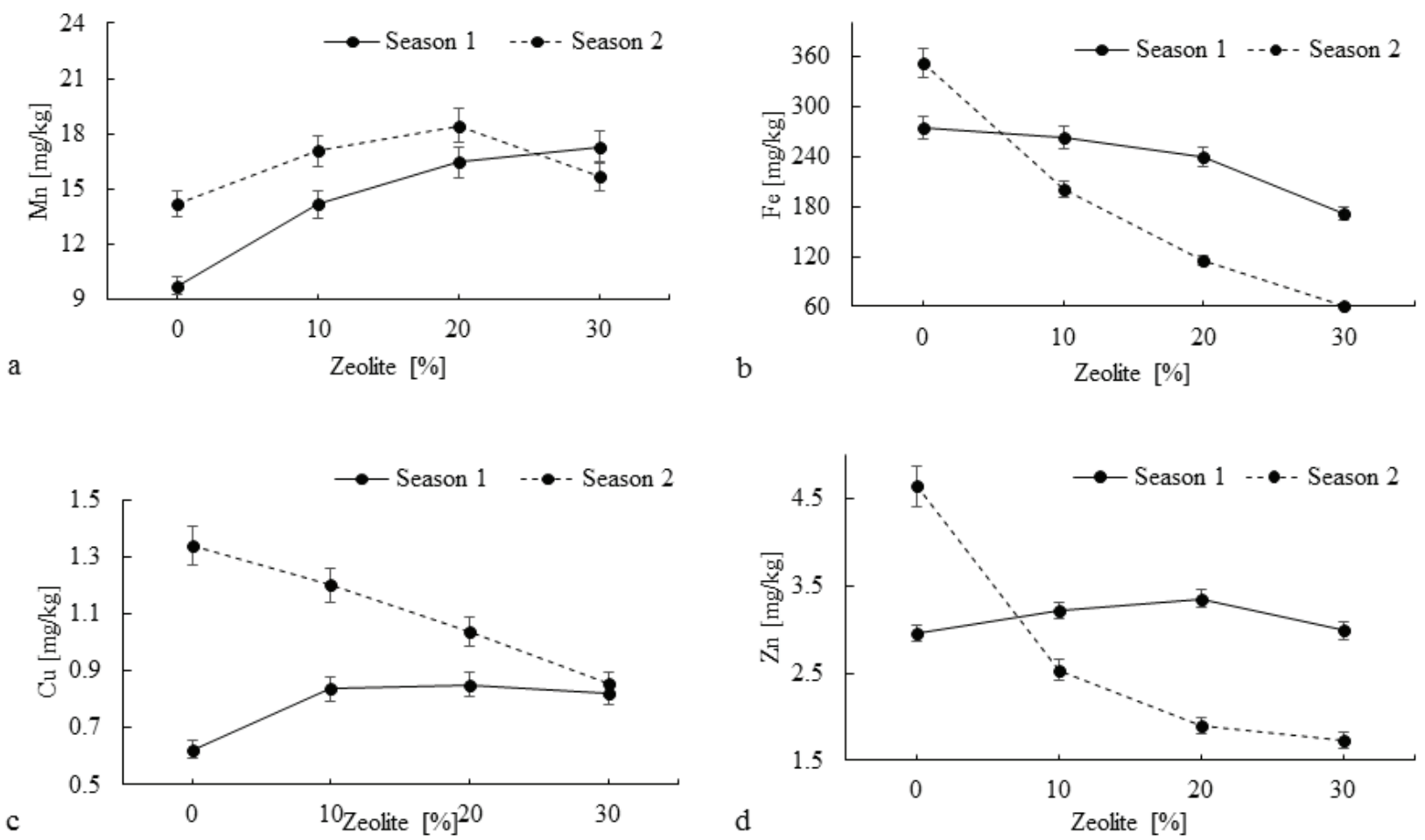

Figure 4. Effect of zeolite on soil trace minerals $(\mathrm{a}-\mathrm{d})$. Overlapping error bars show no significance at $p<0.05$. 
of zinc or intestinal specific conditional knock out of ZIP4 (SLC39A4). Alleviation of these deficiencies is mostly through increased plant intake, so such plants with enhanced $\mathrm{Fe}$ and $\mathrm{Zn}$ contents are of high importance (Mzoughi et al. 2019). In previous studies Jacobs 2011), increased zeolite application to the soil decreased $\mathrm{Zn}$ and $\mathrm{Fe}$ accumulation on Hieracium aurantium and Rumex acetosella. The results in the study were similar, as the highest concentrations of $\mathrm{Fe}$ and $\mathrm{Zn}$ were found in the non-amended treatments. Iron availability is dictated by the soil redox potential and soil $\mathrm{pH}, \mathrm{Fe}$ is readily oxidised at high $\mathrm{pH}$ and is predominantly in the form of ferric oxides (Morrissey \& Guerinot 2009). The accumulation of Fe on the cabbage grown under zeolite amended soil followed this trend and decreased with increased zeolite application which had increased soil $\mathrm{pH}$. Zinc accumulation on the cabbage head was also highest on the non-amended treatment. Zinc assimilation by plants depends on the content and form of $\mathrm{Zn}$, it further depends on the genetic characterises of plants and soil chemical characteristics (Murtic et al. 2017). The accumulation of the micromineral in cabbage in relation to soil $\mathrm{pH}$ proved that heavy metals generally have low solubility at higher $\mathrm{pH}$ as they are normally present in their hydroxide forms
(Singh et al. 2016). In this study, zeolite application did not enhance micromineral accumulation in the cabbage heads. However, the potential environmental availability of heavy metals from contaminated soils may be controlled by soil amendments using exogenous zeolite.

\section{CONCLUSIONS}

Zeolite generally improved the soil chemical status of macrominerals and soil $\mathrm{pH}$. The baseline soil $\mathrm{pH}$ of 5.4 was near the vegetable requirement for critical acidic values for growth. The soil $\mathrm{pH}$ increased significantly after the application of zeolite. However, there was a decrease in phosphorus. The cabbage content of macro minerals was similar under both the zeolite amended and non-amended treatments, except for sodium and potassium. Zeolite did not improve the micro mineral content of cabbage. Soil $\mathrm{Fe}$ and $\mathrm{Mn}$ also decreased compared to non-amended soils. Soil $\mathrm{Zn}$ and $\mathrm{Cu}$ of the second season, and $\mathrm{Fe}$ in both seasons generally decreased with an increase in zeolite application, whereas soil $\mathrm{Zn}$ and $\mathrm{Cu}$ (first season) and $\mathrm{Mn}$ (both seasons) increased even though the soil $\mathrm{pH}$ increased with ze-
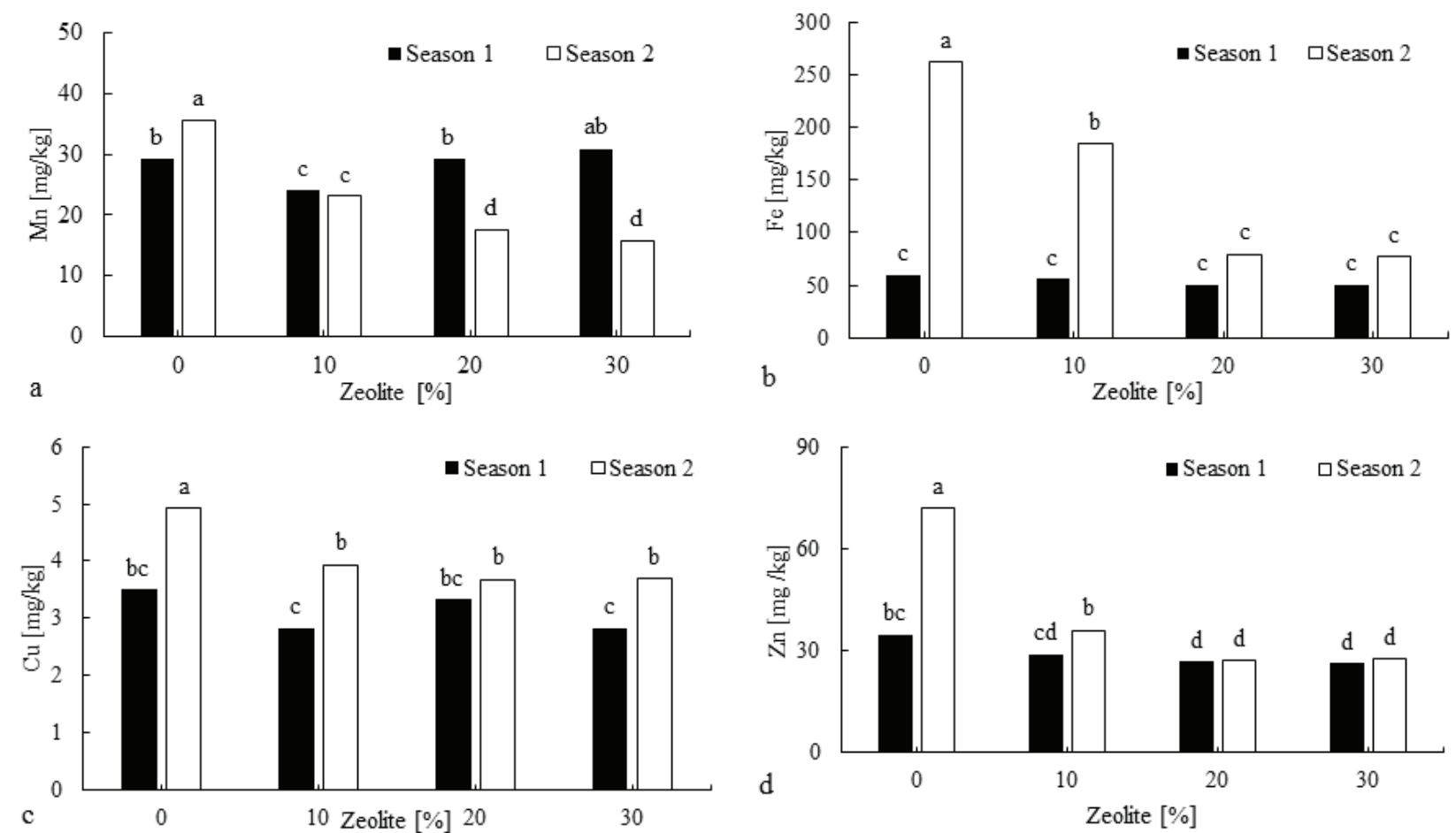

Figure 5. Cabbage microminerals in response to zeolite application. Bars with the same letters show no significance at $p<0.05$. 
olite. This study showed that crops cultivated under zeolite can have some nutrient benefits for macro minerals. However, micromineral enhancement was not observed in this study. Further studies should explore the use of zeolite in combination with other nutrient sources that supply micronutrients.

Acknowledgement: The authors thank the National Research Foundation (NRF) [Grant number: 114405] of South Africa for financial support towards this research. Any opinion, findings and conclusions, or recommendations expressed in this article are those of the author(s), and that the NRF accepts no liability whatsoever in this regard.

\section{REFERENCES}

Afolayan, A.J. \& Jimoh, F.O. (2009). Nutritional quality of some wild leafy vegetables in South Africa. International Journal of Food Sciences and Nutrition, 60(5), 424-431. DOI:10.1080/09637480701777928.

Ahmed, O.H., Husin, A. \& Husni Mohd Hanif, A. (2008). Ammonia volatilization and ammonium accumulation from urea mixed with zeolite and triple superphosphate. Acta Agriculturae Scandinavica, Section B - Plant Soil Science, 58(2), 182-186. DOI:10.1080/09064710701478271.

Bernacchia, R., Preti, R. \& Vinci, G. (2016). Organic and conventional foods: Differences in nutrients. Italian Journal of Food Science, 28(4), 565-578. DOI:10.14674/1120-1770/ ijfs.v224.

Bvenura, C. \& Afolayan, A.J. (2015). The role of wild vegetables in household food security in South Africa: A review. Food Research International, 76, 1001-1011. DOI:10.1016/j. foodres.2015.06.013.

Clemente, R., Walker, D.J. \& Bernal, M.P. (2005). Uptake of heavy metals and as by Brassica juncea grown in a contaminated soil in Aznalcóllar (Spain): The effect of soil amendments. Environmental Pollution, 138(1), 46-58. DOI:10.1016/j.envpol.2005.02.019.

Cvetković, B.R., Pezo, L.L., Mišan, A., Mastilović, J., Kevrešan, Ž., Ilić, N. \& Filipčev, B. (2019). The effects of osmotic dehydration of white cabbage on polyphenols and mineral content. $L W T, 110,332-337$. DOI:10.1016/j. lwt.2019.05.001.

de Campos Bernardi, A.C., Anchão Oliviera, P.P., de Melo Monte, M.B. \& Souza-Barros, F. (2013). Brazilian sedimentary zeolite use in agriculture. Microporous and Mesoporous Materials, 167, 16-21. DOI:10.1016/j.micromeso.2012.06.051.

Eshghi, S., Mahmoodabadi, M.R., Abdi, G.R. \& Jamali, B. (2010). Zeolite ameliorates the adverse effect of cadmium contamination on growth and nodulation of soybean plant (Glycine max L.). Journal of Biological and Environmental Sciences, 4(10), 43-50.

Fornes, F., García-de-la-Fuente, R., Belda, R.M. \& Abad, M. (2009). 'Alperujo' compost amendment of contaminated calcareous and acidic soils: Effects on growth and trace element uptake by five Brassica species. Bioresource Technology, 100(17), 3982-3990. DOI:10.1016/j. biortech.2009.03.050.
Garau, G., Castaldi, P., Santona, L., Deiana, P. \& Melis, P. (2007). Influence of red mud, zeolite and lime on heavy metal immobilization, culturable heterotrophic microbial populations and enzyme activities in a contaminated soil. Geoderma, 142(1-2), 47-57. DOI:10.1016/j.geoderma.2007.07.011.

Gül, A., Eroğul, D. \& Ongun, A.R. (2005). Comparison of the use of zeolite and perlite as substrate for crisp-head lettuce. Scientia Horticulturae, 106(4), 464-471. DOI:10.1016/j. scienta.2005.03.015.

Hazrati, S., Tahmasebi-Sarvestani, Z., Mokhtassi-Bidgoli, A., Modarres-Sanavy, S.A.M., Mohammadi, H. \& Nicola, S. (2017). Effects of zeolite and water stress on growth, yield and chemical compositions of Aloe vera L. Agricultural Water Management, 181, 66-72. DOI:10.1016/j.agwat.2016.11.026.

He, Z.L., Calvert, D.V., Alva,A.K., Li, Y.C.\& Banks, D.J. (2002). Clinoptilolite zeolite and cellulose amendments to reduce ammonia volatilization in a calcareous sandy soil. Plant and Soil, 247(2), 253-260. DOI:10.1023/A:1021584300322.

Headey, D.D. \& Martin, W.J. (2016). The impact of food prices on poverty and food security. Annual Review of Resource Economics, 8(1), 329-351. DOI:10.1146/annurev-resource-100815-095303.

Jacobs, P. (2011). Regenerative farming, indigenous knowledge and climate change: Expand environmentally friendly agriculture in rural Limpopo. Economic Performance and Development; Agriculture and climate change interactions, COP 17 Side Event, November 2011. http://www.hsrc. ac.za/uploads/pageContent/1074/The $\% 20$ Social $\% 20$ Sciences $\% 20 \mathrm{in} \% 20 \mathrm{a} \% 20$ Changing $\% 20$ Climate $\% 20$ Meaningful $\% 20$ knowledge $\% 20$ that $\% 20$ works.pdf.

Kondaiah, P., Yaduvanshi, P.S., Sharp, P.A. \& Pullakhandam, R. (2019). Iron and zinc homeostasis and interactions: Does enteric zinc excretion cross-talk with intestinal iron absorption? Nutrients, 11(8), 1885. DOI:10.3390/nu11081885.

Kukier, U., Peters, C.A., Chaney, R.L., Angle, J.S. \& Roseberg, R.J. (2004). The effect of $\mathrm{pH}$ on metal accumulation in two alyssum species. Journal of Environmental Quality, 33(6), 2090-2102. DOI:10.2134/jeq2004.2090.

Madejón, E., de Mora, A.P., Felipe, E., Burgos, P. \& Cabrera, F. (2006). Soil amendments reduce trace element solubility in a contaminated soil and allow regrowth of natural vegetation. Environmental Pollution, 139(1), 40-52. DOI:10.1016/j.envpol.2005.04.034.

Morrissey, J. \& Guerinot, M.L. (2009). Iron uptake and transport in plants: The good, the bad, and the ionome. Chemical Reviews, 109(10), 4553-4567. DOI:10.1021/cr900112r.

Murtic, S., Civic, H., Koleska, I., Oljaca, R., Behmen, F. \& Avdic, J. (2017). Zinc and copper dynamics in the soil - plant system in intensive strawberry production. International Journal of Plant \& Soil Science, 18(5), 1-7. DOI:10.9734/IJPSS/2017/36454.

Mzoughi, Z., Chahdoura, H., Chakroun, Y., Cámara, M., Fernández-Ruiz, V., Morales, P., Mosbah, H., Flamini, G., Snoussi, M. \& Majdoub, H. (2019). Wild edible Swiss chard leaves (Beta vulgaris L. var. cicla): Nutritional, phytochemical composition and biological activities. Food Research International, 119, 612-621. DOI:10.1016/j. foodres.2018.10.039.

Nur Aainaa, H., Haruna Ahmed, O. \& Ab Majid, N.M. (2018). Effects of clinoptilolite zeolite on phosphorus dynamics and yield of Zea Mays L. cultivated on an acid soil. PLOS ONE, 13(9), e0204401. DOI:10.1371/journal.pone.0204401.

Omar, L., Ahmed, O. \& Muhamad, A. (2011). Effect of mixing urea with zeolite and sago waste water on nutrient use efficiency of maize (Zea mays L.). African Journal 
of Microbiology Research, 5, 3462-3467. DOI:10.5897। AJMR11.637.

Ozbahce, A., Tari, A.F., Gonulal, E. \& Simsekli, N. (2018). Zeolite for enhancing yield and quality of potatoes cultivated under water-deficit conditions. Potato Research, 61(3), 247-259. DOI:10.1007/s11540-018-9372-5.

Ozbahce, A., Tari, A.F., Gönülal, E., Simsekli, N. \& Padem, H. (2015). The effect of zeolite applications on yield components and nutrient uptake of common bean under water stress. Archives of Agronomy and Soil Science, 61(5), 615-626. DOI:10.1080/03650340.2014.946021.

Pasković, I., Herak Ćustić, M., Pecina, M., Bronić, J., Palčić, I., Hančević, K. \& Radić, T. (2013). Impact of modified synthetic zeolite A and mycorrhizal fungi on olive leaf mineral content. Glasnik Zaštite Bilja, 36(4), 35.

Polat, E., Karaca, M., Demir, H. \& Onus, A.N. (2004). Use of natural zeolite (clinoptilolite) in agriculture. Journal of Fruit and Ornamental Plant Reserarch, 12, 183-189.

Ramesh, K. \& Reddy, D.D. (2011). Zeolites and their potential uses in agriculture. In Sparks, D.L. (Ed.), Advances in Agronomy, 113, 219-241. DOI:10.1016/B978-0-12386473-4.00004-X.

Ramesh, V., Jyothi, J.S. \& Shibli, S.M.A. (2015). Effect of zeolites on soil quality, plant growth and nutrient uptake efficiency in sweet potato (Ipomoea batatas L.). Journal of Root Crops, 41(1), 25-31.

Reháková, M., Čuvanová, S., Dzivák, M., Rimár, J. \& Gaval'ová, Z. (2004). Agricultural and agrochemical uses of natural zeolite of the clinoptilolite type. Current Opin- ion in Solid State and Materials Science, 8(6), 397-404. DOI:10.1016/j.cossms.2005.04.004.

Rieuwerts, J.S., Thornton, I., Farago, M.E. \& Ashmore, M.R. (1998). Factors influencing metal bioavailability in soils: preliminary investigations for the development of a critical loads approach for metals. Chemical Speciation \& Bioavailability, 10(2), 61-75. DOI:10.3184/095422998782775835.

Singh, J., Kalamdhad, A.S. \& Lee, B.-K. (2016). Effects of natural zeolites on bioavailability and leachability of heavy metals in the composting process of biodegradable wastes. In Belviso, C. (Ed.), Zeolites - Useful Minerals. InTech. DOI: $10.5772 / 63679$.

Tsadilas, C.D., Dimoyiannis, D. \& Samaras, V. (1997). Effect of zeolite application and soil $\mathrm{pH}$ on cadmium sorption in soils. Communications in Soil Science and Plant Analysis, 28(17-18), 1591-1602. DOI:10.1080/00103629709369899.

Tulchinsky, T.H. (2010). Micronutrient deficiency conditions: Global health issues. Public Health Reviews, 32(1), 243-255. DOI:10.1007/BF03391600.

Zheng, J., Chen, T., Chi, D., Xia, Wu, Q., Liu, G., Chen, W., Meng, W., Chen, Y. and Siddique K.H.M. (2019). Influence of zeolite and phosphorus applications on water use, $\mathrm{P}$ uptake and yield in rice under different irrigation managements. Agronomy, 9(9), 537. DOI:10.3390/agronomy9090537.

Received: April 22, 2021

Accepted: June 16, 2021 